\title{
PW03-027 - CASP1 variants and live cell imaging
}

\author{
S Rabe*, MC Heymann, S Russ, S Winkler, J Roesler, A Rösen-Wolff, SR Hofmann \\ From 7th Congress of International Society of Systemic Auto-Inflammatory Diseases (ISSAID) \\ Lausanne, Switerland. 22-26 May 2013
}

\section{Introduction}

Patients with unexplained recurrent febrile episodes and CASP1 variants suffer from systemic sterile inflammation despite reduced secretion of IL-1ß. As previously demonstrated by our group CASP 1 variants lead to reduced enzymatic activity of procaspase- 1 by destabilizing the tertiary structure of the caspase- 1 tetramer. A possible explanation for an alternative pro-inflammatory pathway has been provided by Lamkanfi and colleagues indicating an association between enzymatically inactive procaspase- 1 and receptor interacting protein kinase 2 (RIP2) leading to NF-kB activation.

\section{Objectives}

The objective of this project is the identification of possible subcellular mechanisms how CASP1 variants interfere with the IL- $1 \beta$ production or release and lead to the activation of alternative pro-inflammatory pathways.

\section{Methods}

Using confocal microscopy, in vivo live cell imaging and an in situ proximity ligation assay we analyzed the subcellular distribution of procaspase- 1 wildtype and mutants as well as the interaction with RIP2 in naïve or virally transduced THP-1 cells.

\section{Results}

THP-1 cells were virally transduced with GFP- or mCherry fusion proteins of procaspase- 1 wildtype and variant CASP1-L265S. Procaspase-1 activation, initiated by the assembly of multiprotein complexes (inflammasomes), was induced by stimulation with LPS and Nigericin. First results suggest disturbed microvesicle shedding from CASP1-L265S expressing cells after administration of Nigericin. In addition to live cell imaging, the interaction of procaspase-1 and RIP2 has been studied in vitro in

Department of Pediatrics, Technical University Dresden, Medical Center Carl Gustav Carus, Dresden, Germany naïve THP-1 cells using antibody labeling and proximity ligation assay showing a time dependency after LPS stimulation.

\section{Conclusion}

This result suggests a possible influence of procaspase-1 variants on plasma membrane properties, pyroptosis and the release of microvesicles.

\section{Disclosure of interest}

None declared.

Published: 8 November 2013

doi:10.1186/1546-0096-11-S1-A253

Cite this article as: Rabe et al:: PW03-027 - CASP1 variants and live cell imaging. Pediatric Rheumatology 2013 11(Suppl 1):A253.

\section{Submit your next manuscript to BioMed Central and take full advantage of: \\ - Convenient online submission \\ - Thorough peer review \\ - No space constraints or color figure charges \\ - Immediate publication on acceptance \\ - Inclusion in PubMed, CAS, Scopus and Google Scholar \\ - Research which is freely available for redistribution

